\title{
Case Study of Pathological Manifestations of Neoprene Support Devices in Infrastructure
}

\author{
Felipe R. Gonçalves ${ }^{1 \mathrm{a}}$, Lais A. Alves ${ }^{2}$, Assed N. Haddad ${ }^{1 \mathrm{~b}}$ and Elaine G. Vazquez $^{1 \mathrm{c}}$ \\ ${ }^{1}$ Escola Politécnica, Department of Civil Construction, Universidade Federal do Rio de Janeiro \\ (UFRJ), Technology Center, Av. Athos da Silveira, 149 CT - Sector A, $2^{\circ}$ floor, 21941-909 - Cidade \\ Universitária, Rio de Janeiro, Brazil, felipe.rezende@poli.ufrj.br, assed@poli.ufrj.br, \\ elainevazquez@poli.ufrj.br \\ ${ }^{2}$ Department of Civil Construction, Federal Center of Technological Education Celso Suckow da \\ Fonseca, Av. Maracanã, 229 Sector E, 2 floor, 20271-110 - Maracanã, Brazil, lais.alves@cefet-rj.br
}

\begin{abstract}
The so-called works of special arts, are constructions of high complexities that allow the advancement of widening gaps and overcoming obstacles previously unthinkable. With the increase in magnitude of these structures, in addition to greater investments, the maintenance of these structures becomes an increasingly important factor for engineering. Among the elements of bridge structures, the support devices are components with important structural functions, being essential for their proper functioning and especially the durability of the entire structure. This paper aims to evaluate the pathological manifestations in support devices so, according to inspections performed and the diagnosis of causes, define their best practices and treatments for the maintenance and mitigation of the pathologies found. In the practical study the following steps were performed: survey and selection of the structures currently under maintenance of MetrôRio; selection of criteria for the evaluation of pathologies; carrying out inspections; comparative analysis between the viaducts to determine the priority order for negotiations; and definition of conduct. The results obtained were the result of evaluation of the field analysis, diagnosis and comparison with tests performed in support devices. Having as input the tests in the support devices, the best treatments and suggestions to avoid new pathologies were proposed.
\end{abstract}

Keywords: Support Device, Infrastructure, Pathological Manifestation, Maintenance.

\section{Introduction}

Throughout history, bridges have been built to exemplify the engineering prowess of a civilization, many enduring longer than the empires that built them (Wilson, 2009).

Bridges and infrastructures systems, due to their inherent vulnerability, are at risk from ageing, fatigue and deterioration process due to aggressive chemical attacks and other physical damage mechanisms (Biondini, 2015). The preventive and corrective maintenance should be part of a comprehensive management process, including periodic surveys aimed at identifying any existing structural anomalies and failures, diagnosing them and then defining recovery and treatment actions, if necessary (Kainuma et al., 2014).

The culture of inspection and maintenance of road bridges, railroads and viaducts in Brazil is recent, being from the 80's the first studies of pathologies in the structures (Araujoa, 2017).

There is a specific standard for the inspection work on bridges, viaducts and concrete walkways, ABNT / NBR 9452/2016 (ABNT NBR 9452, 2016). 
Support devices are components with structural functions essential for the proper functioning and durability of the structure, but not just a sample of the entire structure, the support device alone can already represent a maintenance point of the structure, so its monitoring continuous inspections are considered very important in the bridge maintenance management process (Freire et al., 2015).

It can be said that knowledge of the state of the bearing apparatus is a good sign and well represents the state of the bridges in their entirety in structural terms. Therefore, the analysis of their pathologies, causes and origins is of great importance in defining the treatment and maintenance of bridges, elevations and viaducts. (Freire et al., 2014).

Metal and concrete support devices expose some problems that discourage their use, either in terms of maintenance difficulty, poor property of materials or even the built-in cost. Therefore, over time, it was searched for elements that could cover all the needs of a support device, this way arose the support devices in elastomer, based on polychloroprene, whose widespread trade name is neoprene which as a product industrialized, it presents greater uniformity of physical characteristics, as well as exceptional resistance to light and ozone, thus providing durability significantly superior to that of other types of elastomers (Cordeiro,2014).

This paper aims to present approaches towards improving some specific infrastructure maintenance principles, strategies, models and practices, based on a recent study to evaluate the pathological manifestations in neoprene support devices, of the structures currently under maintenance of MetrôRio.

The novelty of this

deterioration forecasti

Given the importance

system works continu

2 Methods

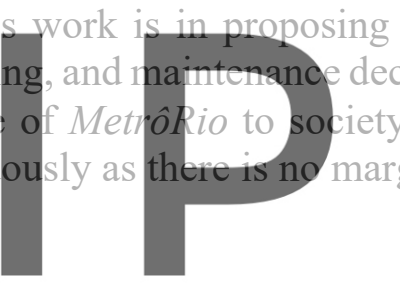

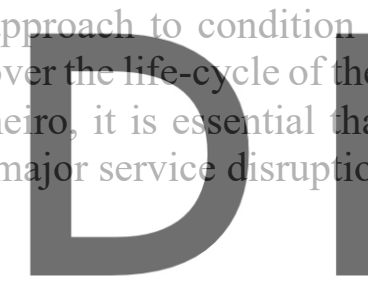

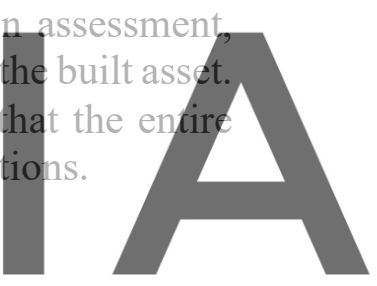

In the methodology the following. steps were used: survey of the viaducts, elevations and

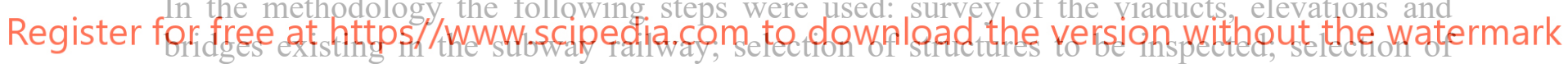
criteria used in the evaluation of pathological manifestations; conducting visual inspections based on ABNT NBR 9452/2016; and suggestions for future interventions.

\subsection{Inspection of Bridges and Support Equipment}

Inspections are paramount to characterize the bridge's constituent elements and, therefore, their classification according to criteria established in ABNT NBR 9452 (2016). Each element is evaluated according to specific visual aspects defined in the standard. According to the same standard, the following types of inspections are considered: cadastral, routine, special and extraordinary.

ABNT NBR9452 (2016) provides in Annex A, a basic roadmap for tokens and cadastral inspections, the proposed initial documents are described such as project data, execution record and changes in the construction phase, previous inspections, among other elements that may provide more inputs for the definition of the causes and better dealings.

Inspection of assistive devices may not be limited to the space in which they are positioned and to the element. It is necessary to identify the general functioning of the studied artwork and to verify the compatibility with the current behavior of the support devices. 
Because of their location, support devices are structural elements that are difficult to inspect, but their behavior must be monitored by inspectors according to the following general procedures in Table 1 (DNIT, 2004).

Table 1. Items to be inspected on assistive devices (DNIT, 2004).

\begin{tabular}{l|l}
\hline $\begin{array}{l}\text { Visually inspect the accessible faces of the } \\
\text { appliance; After a few years of service, small } \\
\text { cracks } 2 \text { to } 3 \mathrm{~mm} \text { deep and } 2 \text { to } 3 \mathrm{~mm} \text { long are } \\
\text { tolerable; }\end{array}$ & $\begin{array}{l}\text { Check that the support device has been } \\
\text { correctly vulcanized and that there are visible } \\
\text { and oxidized charter steel sheets; }\end{array}$ \\
\hline $\begin{array}{l}\text { If there is displacement of the structure, measure } \\
\text { the angles between the surfaces of the structures } \\
\text { in contact with the support apparatus; }\end{array}$ & $\begin{array}{l}\text { Check for defective expansion joints on the } \\
\text { superstructure, very close to the support } \\
\text { device or directly above the device. }\end{array}$ \\
\hline Measure distortions of the support apparatus; & $\begin{array}{l}\text { Check that the support device has been moved } \\
\text { from its original position; }\end{array}$ \\
\hline
\end{tabular}

Check for the presence of oils, greases or any Measure the heights of the support apparatus other substance harmful to the elastomer; at the edges and center points;

According to ABNT NBR9452 (2016), Table 2 can be considered as a parameter for evaluating support equipment, given its condition and the scenario to which it is exposed.
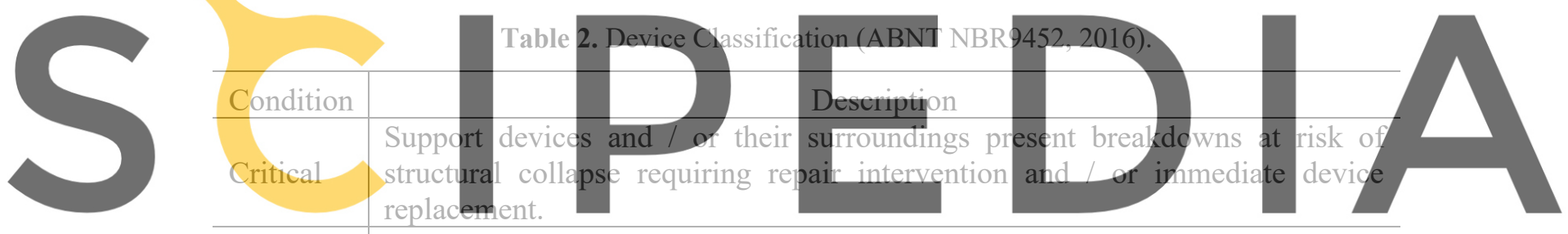

Support devices and / or their surroundings present damage that compromises

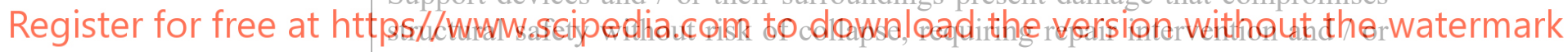

Bad short-term device replacement. All devices with breakage with charter exposure fall into this classification. Follow-up is recommended and interventions may be needed in the short term.

\begin{tabular}{l|l}
\hline Regular & $\begin{array}{l}\text { Support devices and / or their surroundings present malfunctions that may } \\
\text { generate some structural deficiency, but there are no signs of deterioration of the } \\
\text { devices, nor compromise of the stability of the work. Follow-up is recommended } \\
\text { and interventions may be necessary in the medium term. }\end{array}$ \\
\hline Good & $\begin{array}{l}\text { Support devices and / or surroundings are not malfunctioning. Interventions may } \\
\text { be necessary in the long run. }\end{array}$ \\
\hline Excellent & $\begin{array}{l}\text { Support devices and / or their surroundings are not damaged and the devices were } \\
\text { manufactured from 1987 following the recommendations of ABNT NBR } 9783 \\
\text { (1987). }\end{array}$ \\
\hline
\end{tabular}




\subsection{Pathological Manifestation in Neoprene Support Devices}

Although it has excellent performance compared to other types of support equipment, especially when not in need of maintenance, the neoprene device also requires some care. Table 3 shows recurrent pathological manifestations in neoprene supports.

Table 3. Pathological Manifestations in Neoprene Apparatus (Cordeiro, 2014).

\begin{tabular}{c}
\hline Most Common Pathological Manifestations - Neoprene Apparatus \\
\hline High Neoprene Distortion \\
\hline Neoprene cracking or creep \\
\hline Frame contact zone shutdown \\
\hline High compression on neoprene \\
\hline Loss of serviceability and distortion \\
\hline Variations in rubber layer thickness \\
\hline Unsticking of vulcanization of inner sheets \\
Degradation of sliding plates, guides or stops \\
Oxidation of steel elements
\end{tabular}

The causes for the deterioration of structures can be as diverse as the natural "aging" of the structure to the irresponsibility of some professionals who choose to use materials that are out of specification (Souza and Ripper, 1998).
The causes of pathologies in structures have their origins in two groups: intrin
referring to the processes of deterioration inherent in the structure itseff, i.e. its
execution, use, human failures, ete. and extrinsic causes - external to the material b
understood as factors that attack the structures from the outside inwards understood as factors that attack the structures from the outside inwards, throughout the process of conception, execution or the useful life. The most common causes of decreased service life

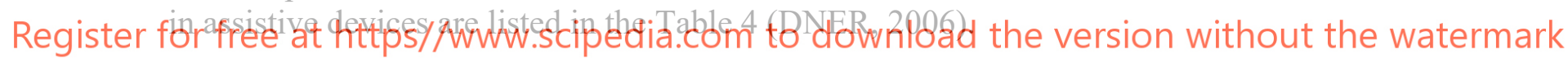

Table 4. Causes of Pathological Manifestations in Support Devices (DNER, 2006).

\begin{tabular}{l|ll}
\hline \multicolumn{3}{c}{ Most common causes of pathological manifestations } \\
\hline $\begin{array}{l}\text { Intrinsic damage not detected during } \\
\text { installation }\end{array}$ & $\begin{array}{l}\text { Irregular seating causing additional } \\
\text { localized overload }\end{array}$ \\
\hline $\begin{array}{l}\text { Displacements, rotations and loads in } \\
\text { service much higher than estimated }\end{array}$ & $\begin{array}{l}\text { Unintended aggressiveness of the } \\
\text { environment }\end{array}$ & Badly nesting in the crib \\
\hline Attack by chemicals & lat & \\
\hline
\end{tabular}

The treatment of a pathological manifestation should be done according to the inspection report, condition and definition of the causes of the given manifestation.

As it is a synthetic structure, of specific manufacture, it is more common that if it presents anomalies, it will be replaced by a new device. Except in the case of incorrect positioning of support devices or displacement of a Teflon sliding plate, for example.

Table 5 presents some common types of repair methods according to each pathology in neoprene support devices (Cordeiro, 2014). 
Table 5. Neoprene Support Devices Treatments - adapted (Cordeiro, 2014).

\begin{tabular}{l|l}
\hline \multicolumn{1}{c|}{ Damage to Support Devices } & \multicolumn{1}{c}{ Repair Dealer } \\
\hline Corrosion, presence of dust and moisture & Cleaning and use of protective paint. \\
\hline Massive corrosion leading to section loss & Replacement \\
\hline Offset or misalignment & Component replacement or total \\
\hline Neoprene deterioration or wear & Replacement \\
\hline Fissures & Crack sealing or replacement \\
\hline Fragmentation of concrete in support & Removal and execution of new concrete \\
\hline
\end{tabular}

\section{Results - Case Study of Pathological Manifestations, Their Causes and Treatments in Neoprene}

All MetrôRio's assets are cataloged according to an asset tree ABNT NBR ISO 55000 (2014), which aims to give an overview, keep all history of interventions, corrective or preventive, and maintenance plans in force combined with each group of systems and equipment. Thus, the support devices studied in this work are under the structures system.

The object of case study was the support devices and their surroundings. The elevations between São Cristóvão and the MetrôRio Maintenance Center and between the Triagem and Maria da Graça stations are the oldest in the system, and their construction dates back to the late 1970s, or about 35 years of operation.

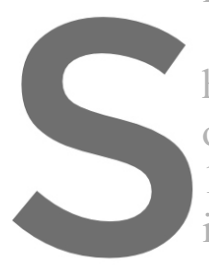

The recommendation

has been posted in a speci

out for the support dev

1228 neoprene suppor

inspections were perforn
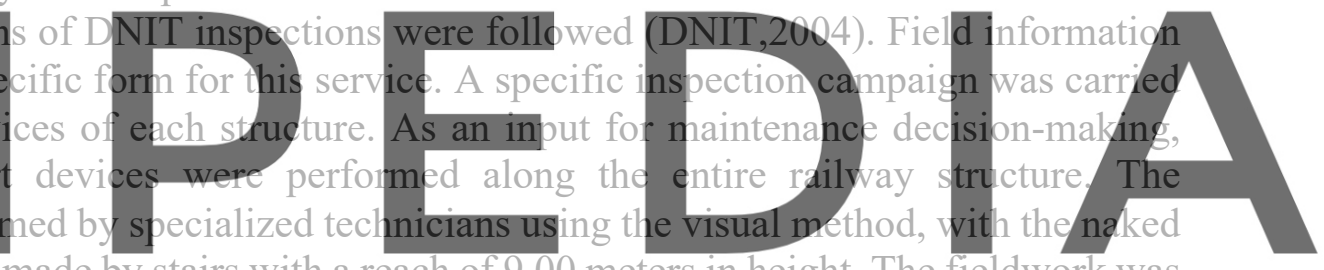

eye, and the access was made by stairs with a reach of 9.00 meters in height. The fieldwork was

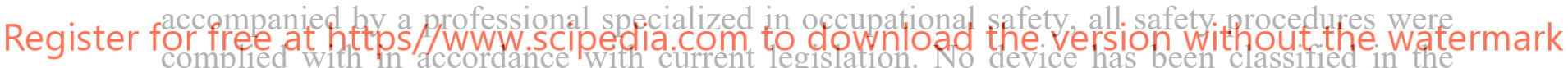

Excellent Class because it is over 30 years old and has not been manufactured (ABNT NBR

9783, 1987).

The CNV - SCR Elevated is located between the Maintenance Center - MC and the São Cristóvão station (later, there was also the connection of the elevated with Cidade Nova station). The old elevation has a total length of $970 \mathrm{~m}$ and consists of 30 spans, 4 spans with 4 beams, 1 span with 3 beam and 25 spans with 2 beams. The trays are seated on 28 pillars and two staked joints at the longitudinal ends, constituting isostatic spans. In the beam $x$ pillar and beam $x$ encounter interface there are chartered neoprene support devices with regular dimensions of $700 \times 250 \times 40 \mathrm{~mm}$. In this elevation, 30 pillars and 138 support devices were evaluated, two of which were not inspected for being covered. It was found that most of the assistive devices (79 units) inspected at this stage were classified as being in a regular state of conservation (57\%). Supporting devices fitted with poor condition total 57 units (42\%), as shown in Fig. 1. 


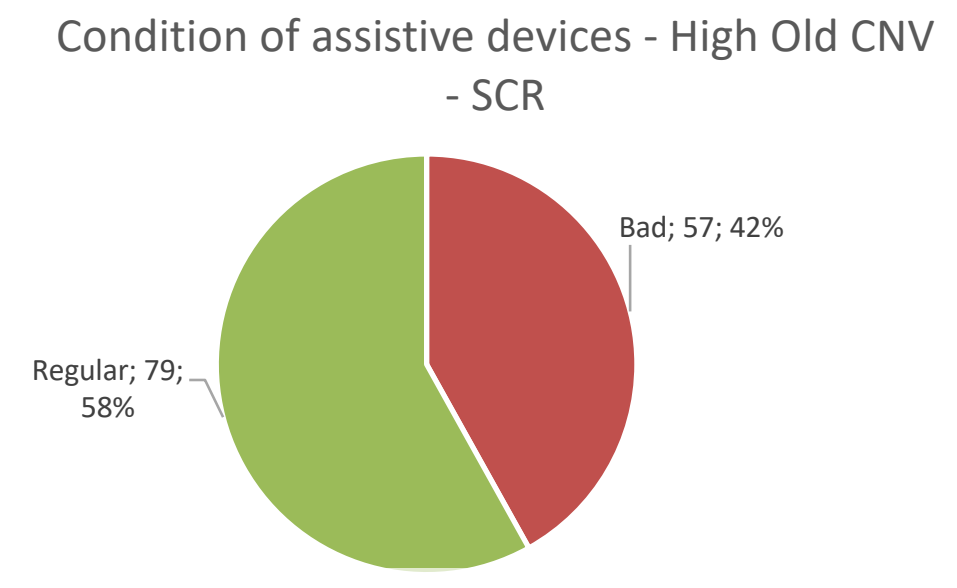

Figure 1. Support Device Conditions - CNV - SCR.

Elevated TRG -MGR is mostly located between the Triagem (TRG) and Maria da Graça (MGR) stations and starts after leaving the Bernold tunnel next to the Mangueira Olympic village. The Elevado has a total length of 2,925 meters and is formed by 84 spans, mostly with 4 precast beams each, with chartered neoprene appliances with dimensions 750 x 200 x 40 mm.

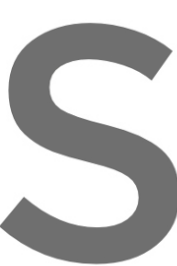
In this elevation, 361 supp they were in a risk area most of the support deri regular state of conser units $(2 \%)$ were conside apport devices were evaluatere access could en
vices (269 units) inspect
vation $(75 \%)$. Poorly clas in good condition a Fig. 2.
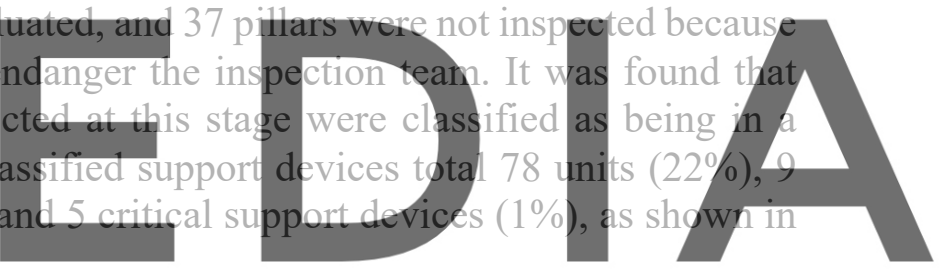

Register for free at https//www.sçpedia.com to download the version without the watermark Conditions

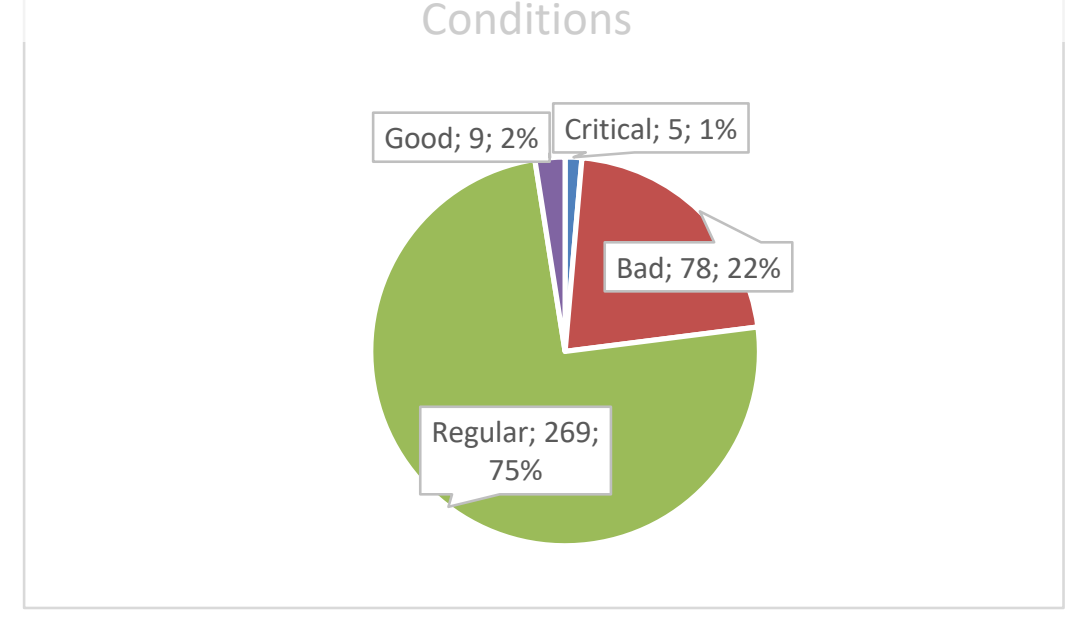

Figure 2. Support Device Conditions - TRG - MGR. 
With the definition of the pillars that concentrated the largest number of critical devices, aiming at a better use of the operation, the decision was made to replace 12 units, from the perspective of urgent replacement. Tables 6 present this pathological manifestation, with the degree of risk, possible cause and the indicated treatment.

Table 6. Pathological manifestations in the devices and support.

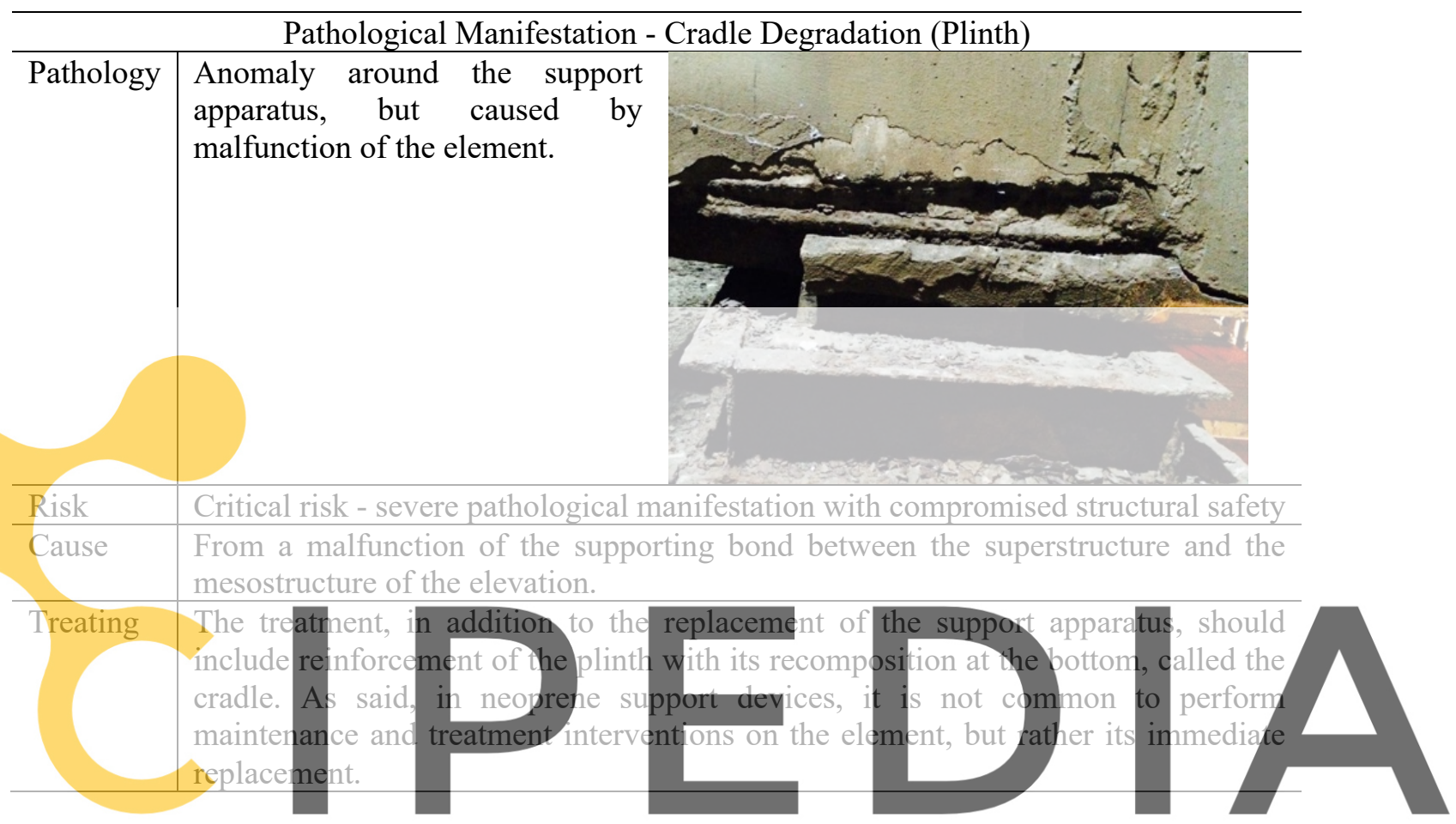

\section{Conclusions}

Register for free at https//www.scipedia.com to download the version without the watermark The concern with the maintenance of structures such as those of special artworks was

motivating for the work and allowed to relate the pathological manifestations in support devices with the pathological manifestations of the structures, the intrinsic and extrinsic causes as a whole, allowing an analysis, albeit superficial in the field of subject matter, sufficient for decision. The novelty was the proposal of a systematic approach to condition assessment, deterioration forecasting, and maintenance decision making over the life-cycle of the built asset.

Supporting devices are structural connecting elements which allow forces to be transmitted between the superstructure of the artwork and its support and are therefore essential elements for the proper functioning of the structure into which they are inserted.

The inspection processes took place exactly in accordance with all the literature found, allowing great inputs for subsequent decision making. Thus, the pathological manifestations were quite explicit.

As for the causes of the manifestations, it is a complex study and although there is literature, it is not trivial to understand the reason why two support devices, theoretically manufactured under the same process, of the same age, suppose stored in the same form, are adjacent to each other, exposed to very close loads and exhibit behaviors so distinct in terms of behavior in service. 
Even with breakage and chartering exposed in the corrosion process, the devices can still perform satisfactorily without causing movement restriction of the part. But in these cases, annual monitoring is essential to follow up on a case-by-case basis to make sure that the performance and operation of the chartered neoprene parts is still adequate.

As for the process of negotiations, in cases where no substitution was considered, monitoring will take place in accordance with the first inspection. Thus, the big point of the issue of support devices is to understand their operation not individually but in conjunction with adjacent structures, as it is evident that despite some anomalies found, support devices, except those that had signs of degradation around them, they were still able to remain in service, provided they were well monitored.

\section{ORCID}

Lais Alves: https://orcid.org/0000-0003-0543-2374

Assed Haddad: https://orcid.org/0000-0002-4793-0905

Elaine Vazquez: https://orcid.org/0000-0002-7262-6753

\section{References}

Araujoa C. (2017). Main aspects covered in ABNT NBR 9452: 2016, the importance of maintenance activities in bridges and viaducts and the difficulties of the conditions of access to the inspections. Revista IPT $\mid$ Tecnologia

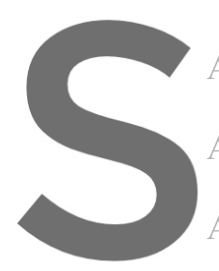
e Inovação 1(5), 1-12

Associação Brasileira de 1 or princípios e terminolo

Associação Brasileira de No concreto armado e protendido

Associação Brasileira de passarelas de concreto. Rio de J
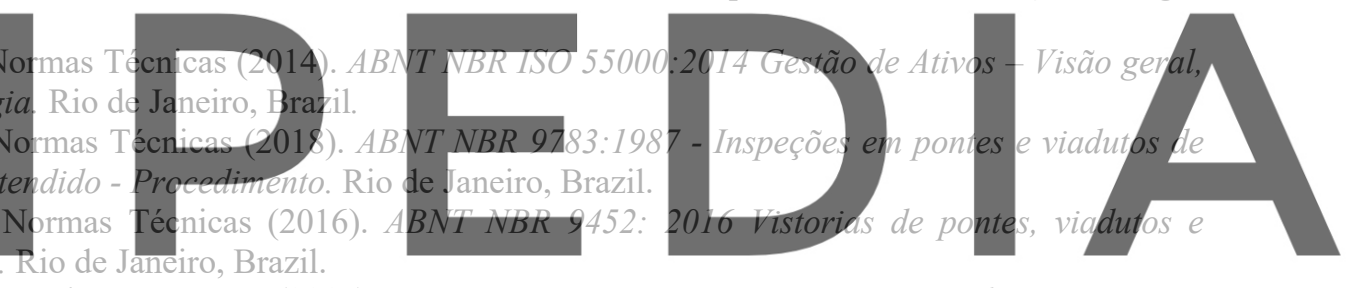

Biondini F. and Frangopol Dan M. (2015). Design, assessment, monitoring and maintenance

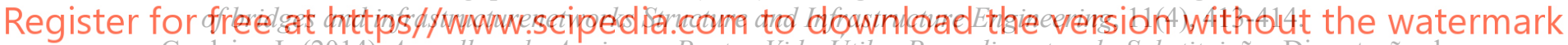

Cordeiro J. (2014) Aparelhos de Apoio em Pontes Vida Util e Procedimentos de Substituição. Dissertação de Mestrado. ISEL (Instituto Superior de Engenharia de Lisboa). Lisboa, Portugal.

Departamento de Estradas e Rodagem (DNER) (2006). Substituição de aparelhos de apoio e juntas de dilatação - Código 020. São Paulo, Brazil.

Departamento Nacional de Infra-Estrutura de Transportes (DNIT) (2004). Manual de Inspeção de Pontes Rodoviárias, $2^{\text {a }}$ Edição, Rio de Janeiro, Brazil.

Freire L., Brito J. de and Correia J. (2015). Inspection Survey of Support Bearings I Road Bridges. Journal of Performance of Constructed Facilities, Vol.29(4), 100-112.

Freire L., Brito J. de and Correia J. (2014). Management system for road bridge structural bearings Structure and Infrastructure Engineering, 10(8), 1068-1086.

Kainuma S., Ahn J-H., Jeong Y-S., Imamura T. and Matsuda T. (2014). Applicability and structural response for bearing system replacement in suspension bridge rehabilitation, Journal of Constructional Steel Research, 95(19), 172-192.

Souza V., Ripper T. (1998). Patologia, Recuperação e Reforço de Estruturas de Concreto. 1 ed. São Paulo, Brazil, Ed. Pini.

Wilson K. (2009). Building bridges: from simple stone spans to complex constructions of iron and concrete, Britain's abundance of bridges offers endless opportunities for photographic creativity. (GEO photo) Cengage Learning, Inc. Geographical, 81(9), 82 -97. 